\title{
МИСТЕЦТВОЗНАВСТВО
}

DOI: https://doi.org/10.32839/2304-5809/2020-1-77-35

UDC 37.013.43: 781.2

Churkina Victoria, Voronina Halyna

Kharkov Academy of Postgraduate Education

\section{INAUGURAL INTELLIGENCE OF UKRAINIAN FOLK SONG BY HRYHORIY NUDHA}

Summary. In the article the analysis of H. Nudha's research of functioning of the Ukrainian folk song in the non-national environment is analyzed. The song and thought as the most widespread and richest genre of Ukrainian folklore is a testimony to the integration of the Ukrainian song melos into the world ethnomusicological cultural atmosphere in the process of cultural dialogue. Together with songs, the world is increasing attention to life, customs and history of Ukrainians. In many studies, Hrygoriy Nudha describes the emergence and development of the Ukrainian epic tradition. Hrygoriy Nudha considered and analyzed the literary, cultural and educational processes of the past of Ukraine as a continuous development and improvement of the spiritual world of the people. Based on the facts, H. Nudga convinced the readers that literature, folklore, culture of Kievan Rus is a unique creation of the Ukrainian people. He noted that the Ukrainian song is "the soul of the Ukrainian people, it is its glory". In his explorations he highlighted the question of the place and role of Ukrainian song in world culture. Based on the huge factual material collected from all over the world, H. Nudga convincingly proved that song and thought are the most significant and original contribution of the Ukrainian people to the treasury of the world's peoples culture. For, music and poetry are the achievements of the world's folk art. Minor in melody, the Ukrainian song impressed musicologists and folklorists of Europe. Ukrainian words and historical songs have been preserved and formed the basis of the repertoire of Ukrainian kobzars and lyricists for centuries. Folk songwriting covers all spheres of human life. Traditional musical and ethnic culture is still preserved to this day still in a pure enough form. The songs help to better understand the spiritual world of the people, teach them to understand and love national art.

Keywords: non-national environment, integration, folk song, thought, folklore genre, history.

Чуркіна В.Г., Вороніна Г.Л. Харківська академія неперервної освіти

\section{ІННОВАЦІЙНІ РОЗВІДКИ УКРАЇНСЬКОЇ НАРОДНОЇ ПІСНІ ГРИГОРІЯ НУДЬГИ}

\begin{abstract}
Анотація. Стаття висвітлюе актуальні проблеми сучасної культурології, фольклористики та присвячена аналізу наукового доробку Григорія Нудьги щодо інонаціональних розвідок української народної пісні, що має особливе значення для філологічних та фольклористичних досліджень та є унікальним як за своєю сутністю, так і за обсягом вивчення величезної джерельної бази, яку згромадив учений упродовж довгих років копіткої праці. Наукові розвідки дослідника прикметні надзвичайно широким діапазоном пошуків у сфрері усної словесності, літератури, історії культури, фрілософрії, етномузикології та генології, скрупульозністю, точністю та об'єктивністю наукових спостережень, глибинним зондажем діахронного й синхронного зрізів досліджуваних явищ, вивченням історичних фактів, всебічністю та своерідним синкретизмом аналітичних висновків. Ученим доведено, що українська культурологічна та суспільствознавча науки, на жаль, ще недостатньо приділяють увагу проблемі впливу української народної пісня на фоормування та розвиток фольклорної спадщини народів Свропи. У зв'язку з цим автори намагаються висвітлити наукові підходи Г.Нудьги до вивчення української та загальноевропейської традиції про народну творчість, які тривалий час панування соціалістичної ідеології ігнорувалися. У статті проаналізовано дослідження Г.Нудьги щодо фрункціонування української народної пісні в інонаціональному середовищі. У розумінні фольклориста особливим чином переломилися ідеї інтернаціоналізму. Пісня й дума як найпоширеніший та найбагатший жанр українського фольклору е свідченням інтеграції українського пісенного мелосу до світової етномузикологічної культурної атмосфери в процесі діалогу культур. Разом з піснями світом посилюеться увага до побуту, звичаїв, історії українців. Г.Нудьга в численних розвідках про українську думу і пісню в світі підкреслюе, що українська пісня висвітлюе величезну силу творчого генія українського народу, розкривае багатство його душі та творчості. Цінні відомості дослідник подає про цікаві сторінки пісенних взаємин української пісні з творчістю народів Європи.
\end{abstract}

Ключові слова: інонащіональне середовище, інтегращія, народна пісня, дума, фрольклорний жанр, історія.

Droblem statement. The prominent writer

H. Nudha entered the literature in the middle of the last century. His ideological and creative development was complex. The contradictions of that era could only be untangled and explained through the study of history. In particular, the idea of internationalism was broken by the folklorist: he sought to overcome the narrow national secrecy of his reader's perception and to open up to him a panorama of major historical events all over the world [4, p. 37].
The problem of Ukrainian folk song and its role in contemporary Ukrainian culture has been addressed by such researchers as S. Naumenko, O. Katrych, M. Chabad, D. Cherednichenko, L. Kulik, and others. They noted that each folklore genre is characterized by certain features, in particular in thoughts, historical, social and everyday songs, there is a social, public sound.

Analysis of resent research and publications. Researchers of the Ukrainian mentality have 
repeatedly addressed this song genre of Ukrainian folklore. M. Kostomarov, O. Potebnya, M. Drahomanov, V. Antonovich, M. Sumtsov, I. Franko, M. Hrushevsky, other folklorists, historians, literary critics and linguists relied on the song material in their scientific works. Taking into account the experience of O. Potebnya, M. Lysenko, P. Sokalsky, F. Kolessa in the study of songs and thoughts, in particular musical characteristics, rhythmic composition, motives and style, H. Nudha first applied a synthetic method to understanding the nature of the genre, features of performance. The scientist noted the lyric-epicness and realism of thoughts, such a significant feature as recitation, emphasized the improvisational nature of the performance, layers ("making") in folklore works, for the first time in folkloristics, introduced the "rule of division of the kobzars [2].

The methodological approach to folklore as a type of culture, which expresses the picture of the subject's world and the system of its socio-cultural orientations, makes it possible to understand its transformation and historical socio-dynamics.

In Ukrainian folklore, unfortunately, the great national treasure of song poetics and stylistics has not been sufficiently worked out. In addition, modest developments in this area are mainly performed in the philological aspect on the analysis of the verbal "substance" of the work, mostly without regard to F. Kolessa's argumentative claim that the song tune is the main form in which all this verbal "substance" is cast, with all its lexical stylistic configurations. It is precisely the phonomorphology and phonostylistics of folk song poetics that I would like to draw more attention to.

Formulation of aims of the article (problem statement). The purpose of the article is to study the theme of functioning of Ukrainian folk song in the non-national environment, which is crucial for the scientific activity of Hryhoriy Nudha [8].

Statement of the basic material. For centuries, Ukrainians have created an extremely sophisticated genre of folk song and thought. Dumas have long since become, as the English scientist V. Ralston argued, "a matter of national pride for Ukrainians." The epic is the face of the nation, the historical dimension of its maturity, stability and unity, a sign of affirmation of the important socio-political condition that is called for each people, a sense of their place in world history, responsibility for the fate of each person and the whole people as a whole, for his future. For centuries the Ukrainian Duma has been transmitted by Homers of Ukraine-kobzars, who warmed them with their feelings, chivalry in love, the scope of Cossack bravery and philosophical attitude. In the preface "The thought of the beauty, power and glory of the Ukrainian song" to the two-volume, the largest and the most ambitious in the scientific work of $\mathrm{H}$. Nudha, Roman Kirchiv wrote: in both the national and non-Ukrainian cultural contexts, they could not fail to bring it to the subject. H. Nudha already in early works refers to the information about the distribution of Ukrainian songs outside Ukraine many [6, p. 8].

H. Nudha noted: "Speaking about the contribution of the Ukrainian people to world culture, song and thought are the most visible and richest gift of Ukraine placed in the world treasury. This is unanimously stated by representatives of almost all peoples [6, p. 31]." The author has been collecting material for a kind of "international biography" of Ukrainian song for 20 years. For example, Hryhoriy Antonovych points out that the well-known Ukrainian communi- ty songs "Oy on the mountain and the reapers reap", "Standing in the maple over the water", Oy on the mountain and the reapers reaping"," Is not that the Hops "belong to the most interesting examples of Ukrainian folk Poems, which have been preserved in Polish manuscript sources, are interesting, noted H. Nudha, that the older the collections, the more they contain Ukrainian songs [5, p. 89].

The penetration of some Ukrainian songs into the Czech life, wrote H. Nudha, is observed in the nineteenth century, and in the history of this phenomenon he stated unusual facts. In the early nineteenth century. The Czech song "Mountain, High Mountain" became popular in the Czech Republic. Half a century later, a well-known Czech researcher, Ludwig Cuba, came across it in Mykhailo Maximovich's collection "Ukrainian Folk Songs" (1834) and was very surprised that the Czech text was no different from the Ukrainian original of much earlier origin. He also found that the song was transformed into Romanian folklore [5, p. 111].

The researcher wrote that along with the growing popularity of Cossacks in Europe, in particular in Germany, attention to their life, customs and songs was increasing. In the German archives of the XVII century. There are collections of songs and melodies where "along with the works of European composers, there are also specimens of Ukrainian folklore creativity". H. Nudha believed that even the first lexical borrowings from the Ukrainian language into German can be attributed to the 16 th century. (the words "Cossack", "Otaman" etc.). And in the coming centuries (XVI-XX centuries) the German language learned such words as "thought", "bandura", "bandurist", "hopak" [5, p. 216].

One by one articles were published about the Ukrainian song in Hungary, Denmark, France, Germany, England, Yugoslavia, Italy. H.Nudha noted that the process of integration of the Ukrainian song melos into the world ethno-musical and cultural atmosphere took place in the process of dialogue of cultures. The ethnographer has covered the integration of Ukrainian song melos in more than 40 publications, often very sensational.

Extremely valuable information is provided by $H$. Nudha about the interesting pages of Ukrainian-German song relationships that began with the penetration of popular Ukrainian songs into the life and folklore of the German people. The first swallow, the researcher said, was the song-romance "Cossack Riding the Danube". "Her hike around the world is just amazing, almost fabulous." In many countries, it is considered a heritage. "There is hardly any work in the history of European song culture that would be so popular in the first half of the nineteenth century. It is still sung in Germany, Bulgaria, Hungary, the United States, Canada and other countries. In Germany it has become popular. song and has been included in many folklore collections [5, p. 224]. "Among the interesting facts of the "international biography" of Ukrainian song and thought are the following. In Belgium, as in many other countries, Shchedryk's particular interest in the treatment of Mykola Leontovich [5, p. 282]. In the UK more than two hundred years ago, the song "Riding the Cossack over the Danube" was first translated and published in English [5, p. 307]. In France, the Ukrainian words "Samuel the Cat", "Escape of Three Brothers from Azov", "Marusia Bohuslavka" and others were actively translated. 
The French researchers consider these words the most perfect and the most dramatic [5, p. 338].

Nineteenth century. The number of Italian authors who write about Ukraine and its folk poetry is expanding. Professor Domenico Champoli (1855-1929), a Slavician, author of many works on Russian and Ukrainian culture, was the most prominent among them [3, p. 119]. Of all kinds of folk art, the song reveals the wealth of the soul of the people, its creative powers [7, p. 99].

The folklorists emphasized the enormous power of the creative genius of the Ukrainian people, manifested in the Ukrainian song. In his numerous explorations of the Ukrainian thought and song in the world, researcher $H$. Nudha claims that among the deputies and popularizers of the folk song was a wellknown French humanist scientist, the originator of the essay genre, which "was the first to emphasize the aesthetic value of the folk song" Michel de Montaigne (1533-1592), J. Herder (1744-1803), who suggested that the beginnings of history and art should be sought in the environment of the common people, J. Wenzig, X. Tidge, K. Waldbril, F. Bodenstedt, Y. Slavatsky, A. Mickiewicz, J. Shafarik, Y. Kollar, V. Hanka, V. Bethoven, F. List, M. Hlinka and others artists.

"Herder puts forward the thesis," wrote H. Nudha, "that the beginnings of history should be sought in the environment of the common people. In folk poetry, including songs, the soul of the people is laid. Singers, bards, kobzars are the voice of the people. Folk poetry is of great historical and aesthetic value, it is a "means of brotherhood of peoples", it must be recorded, published, studied. The voices of the songs are a world symphony" [3, p. 101].

In the article "Ukrainian song in connection with world culture" H. Nudha noted: "From the artistic features of Ukrainian songs, foreign cultural figures emphasize the natural richness and depth of feelings that are revealed in the songs strongly, simply and briefly ... Poetic maturity and weight images, delicacy of expression, grace, grandeur, democracy and many other fine features are noted by philologists and musicologists when talking about Ukrainian song and its world glory" [7, p. 112].

From a scientific point of view, folk song is a deep traditional and modern oral art. And in content life itself, its interests, connection with history, national consciousness and social feelings. Her role cannot be underestimated, as she has always been a leading figure in personal education. Folk art is the starting point from which the history of the culture of the Ukrainian people begins [1, p. 194].

Folk songwriting covers all spheres of human life. Contrary to the natural tradition of levelling and extinction of authentically distinctive features, traditional musical and ethnic culture is still preserved to this day, though incomplete, but still in a pure enough form. The power of such music lies in its humanity, simplicity and naturalness. The Ukrainian song is characterized by strength, joy of life and humour [7, p. 118-119], and it is they who seek it both in the world and in the song treasury. Folk music drives the listener to empathize, awakens his soul, activates genetic memory, develops artistic thinking. Folk music, including song, has great educational potential. In the songs we find information about the historical past, traditions and way of life of the Ukrainian people, ideas about themselves and the world around them. It is in the folk songs that the whole past fate, the true character of Ukraine, poured out. We regard them as living witnesses to the distant and anxious, bitter lives of our ancestors [9, p. 68].

Conclusions from this study. As we can see, in many explorations, Hrygoriy Nudha considers the emergence and development of the Ukrainian epic tradition. The songs help to better understand the spiritual world of the people, teach them to understand and love national art, unite people spiritually.

\section{References:}

1. O prostonarodnykh pesniakh. Vestnyk Evropy. 1827. Ch. 154. № 11. S. 194-196. (in Russian)

2. Kolessa, F.M. Melodii ukrainskykh narodnykh dum / pidhot. do druku S.Y. Hrytsa. Kyiv, 1969. 598 s. (in Ukrainian)

3. Nudha, H.A. Pisni ukrainskykh poetiv ta yikh narodni pererobky. Pisni ta romansy ukrainskykh poetiv: U 2 t. Kyiv: Rad. pysmennyk, 1956. T. 1. S. 3-103. (in Ukrainian)

4. Nudha, H. Ne biisia smerti. Kyiv: Radianskyi pysmennyk, 1991. 431 s. (in Ukrainian)

5. Nudha, H. U koli svitovoi kultury / vidp. red. V. Ivashkiv; uporiad. R. Markiv; pisliamova L. Harasym. Lviv: Lvivskyi natsionalnyi universytet im. I. Franka, 2006. 440 s. (in Ukrainian)

6. Nudha, H. Ukrainska duma i pisnia v sviti: U 2-kh kn. Lviv: In-t narodoznavstva NAN Ukrainy, 1997. Kn. 1. 420 s. (in Ukrainian)

7. Nudha, H. Ukrainski dumy u Frantsii: Na dopomohu vchytelevi. Narodna tvorchist ta etnohrafiia. 1964 . № 5. S. 76-85. (in Ukrainian)

8. Pylypchuk, S. "Halytsko-ruski narodni prypovidky": paremiolohichno-paremiohrafichna kontseptsiia Ivana Franka. Lviv: Vydavnychyi tsentr LNU imeni Ivana Franka, 2008. 219 s. (in Ukrainian)

9. Rusyn, M.Y. Folklor: tradytsii i suchasnist. Kyiv, 1991. 101 s. (in Ukrainian)

\section{Список літератури:}

1. О простонародных песнях. Вестник Европы. 1827. Ч. 154. № 11. С. 194-196.

2. Колесса Ф.М. Мелодії українських народних дум / підгот. до друку С.Й. Грица. Київ, 1969. 598 с.

3. Нудьга Г.А. Пісні українських поетів та їх народні переробки. Пісні та романси українських поетів: У 2 т. Київ : Рад. письменник, 1956. Т. 1. С. 3-103.

4. Нудьга Г. Не бійся смерті. Київ : Радянський письменник, 1991. 431 с.

5. Нудьга Г. У колі світової культури / відп. ред. В. Івашків; упоряд. Р. Марків; післямова Л. Гарасим. Львів : Львівський національний університет ім. І. Франка, 2006. 440 с.

6. Нудьга Г. Українська дума і пісня в світі: У 2-х кн. Львів : Ін-т народознавства НАН України, 1997. Кн. 1. 420 с.

7. Нудьга Г. Українські думи у Франції: На допомогу вчителеві. Народна творчість та етнографія. 1964. № 5. C. $76-85$.

8. Пилипчук С. «Галицько-руські народні приповідки»: пареміологічно-пареміографрічна концепція Івана Франка. Львів : Видавничий центр ЛНУ імені Івана Франка, 2008. 219 с.

9. Русин М.Ю. Фольклор: традиції і сучасність. Київ, 1991. 101 с. 